\title{
Implementasi Data Mining Untuk Memprediksi Target Pemakaian Stok Barang Menggunakan Metode Regresi Linier Berganda
}

\author{
Firahmi Rizky, Yohanni Syahra, Ita Mariami, Yusnawati \\ Program Studi Sistem Informasi, STMIK Triguna Dharma
}

\begin{tabular}{|c|c|}
\hline Article Info & בABSTRACT \\
\hline $\begin{array}{l}\text { Article history: } \\
\text { Received May } 31^{\text {th }}, 2019 \\
\text { Revised June } 12^{\text {th }}, 2019 \\
\text { Accepted Augs 03 } 03^{\text {th }}, 2019\end{array}$ & $\begin{array}{l}\text { Masyarakat sekarang ini hampir seluruhnya mengkonsumsi makanan dan } \\
\text { minuman diluar rumah. Oleh sebab itu, penjualan makanan dan minuman } \\
\text { mulai meningkat dan persaingan dalam bisnis penjualan makanan dan } \\
\text { minuman juga semakin meningkat. Dalam peningkatan jumlah penjualan } \\
\text { baru, maka sebuah perusahaan memerlukan target pemakaian stok barang } \\
\text { yang baik. Dalam memprediksi untuk kedepannya sering kali pihak }\end{array}$ \\
\hline $\begin{array}{l}\text { Keyword: } \\
\text { Data Mining } \\
\text { Algoritma Regresi Linier } \\
\text { Berganda } \\
\text { Target Pemakaian Stok Barang }\end{array}$ & $\begin{array}{l}\text { perusahaan salah memperkirakan target pemakaian stok barang. Maka dari } \\
\text { itu perlu adanya sebuah prediksi yang akurat dan dapat membantu } \\
\text { perusahaan makanan dalam menerapkan target pemakaian stok barang. } \\
\text { Untuk dapat menyelesaikan permasalahan yang ada maka salah satu cara } \\
\text { yang dapat dilakukan untuk memprediksi pemakaian stok barang adalah } \\
\text { dengan menggunakan teknik data mining. Adapun teknik yang digunakan } \\
\text { dalam hal ini adalah Algoritma Regresi Linier berganda. Regresi Linier } \\
\text { berganda adalah Sebagai kajian terhadap ketergantungan satu variabel } \\
\text { dengan variabel lain dengan tujuan membuat estimasi rata-rata nilai variabel } \\
\text { yang sudah diketahui. } \\
\text { Hasil dari penelitian ini adalah, Penjualan barang yang memiliki keterkaitan / } \\
\text { hubungan yang diolah dengan teknik data mining menggunakan algoritma } \\
\text { regresi linier berganda dapat membantu pihak Managemen perusahaan dalam } \\
\text { menentukan stok barang dibulan-bulan berikutnya. }\end{array}$ \\
\hline
\end{tabular}

Copyright @ 2019 STMIK Triguna Dharma. All rights reserved.

\begin{tabular}{ll}
\hline First Author & \\
Nama & :Firahmi Rizky \\
Kantor & :STMIK Triguna Dharma \\
Program Studi & :SistemInformasi \\
E-Mail & :firahmi.rizky@ gmail.com
\end{tabular}

\section{PENDAHULUAN}

Perusahaan yang memfokuskan diri menjual berbagai jenis makanan dan minuman, dalam peningkatan penjualan baru sering kali restauran ini salah dalam memprediksi stok barang, maka dari itu perlu adanya sebuah prediksi yang akurat agar dapat membantu Perusahaan makanan dalam menerapkan target pemakaian stok barang. Oleh karena itu, untuk meminimalisir kesalahan yang terjadi maka untuk penelitian ini akan menerapkan data mining dalam menentukan stok barang yang akurat.

DataMining adalah langkah analisis terhadap proses penemuan pengetahuan di dalam basis data atau knowledge discovery in database (KDD).Dalam Data Miningterdapat beberapa teknik salah satunya adalah estimasi/prediksi. Estimasi digunakan untuk menganalisis stok barang yang akan digunakan dibulan-bulan berikutnya. Algoritma yang akan diterapkan dari estimasi ini adalah Regresi Linier Berganda.

\section{METODE PENELITIAN}

\subsection{Stok Barang}

Stok barang merupakan persediaan barang yang disimpan untuk digunakan atau dijual pada hari-hari berikutnya.

Fungsi stok barang :

1. Mengantisipasi keterlambatan datangnya barang. 
2. Menjamin kelancaran proses produksi dan pelayanan terhadap konsumen.

3. Ruang penyimpanan yang digunakan lebih sedikit.

4. Persediaan selalu baru.

\subsection{Data Mining}

Menurut Fayyad et al (dalam Suyanto 2017 : 1) "Data Mining adalah langkah analisis terhadap proses penemuan pengetahuan di dalam basis data atau knowledge discovery in databases yang disingkat KDD”.

\subsection{Algoritma Regresi Linier Berganda}

Regresi linier berganda adalah sebagai kajian terhadap ketergantungan satu variabel dengan variabel lain dengan tujuan membuat estimasi rata-rata nilai variabel yang sudah diketahui.Berikut merupakan Langkah-langkah dari penerapan metode regresi linier berganda adalah sebagai berikut :

1. Identifikasi variabel penyebab $\left(\mathrm{X}_{1}, \mathrm{X}_{2}, \ldots \mathrm{X}_{\mathrm{n}}\right)$ dan variabel akibat (Y) dari data.

2. Hitung nilai sigma (jumlah total data) dari masing-masing variabel $\left(\sum \mathrm{X}_{1} \sum \mathrm{X}_{2} \cdot \sum \mathrm{X}_{1}^{2} \cdot \sum \mathrm{X}_{2}^{2} \cdot \sum \mathrm{X}_{1} \mathrm{X}_{2}\right.$ $\sum \mathrm{Y}$ dan $\left.\sum \mathrm{Y}^{2}\right)$

3. Buat persamaan linier dengan nilai sigma yang diperoleh sebelumnya dengan rumus.

Persamaan I

Persamaan 2

$$
\sum Y=a n+a_{1} \sum X_{1}+b_{2} \sum X_{2}
$$

Persamaan 3

$$
\sum Y X_{l}=a \sum X_{1}+b_{1} \sum X_{l}^{2}+b_{2} \sum X_{1} X_{2}
$$

$$
\sum Y X_{2}=a \sum X_{2}+b_{1} \sum X_{1} X_{2}+b_{2} \sum X_{2}^{2}
$$

4. Lakukan penghitungan berdasarkan 3 persamaan yang ada sehingga diperoleh nilai $a, b_{1}$ dan $b_{2}$.

5. Buat model persamaan linier dengan nilai $a, b_{1} b_{2}$

$Y=a+b_{1} X_{1}+b_{2} X_{2}$

Keterangan :
$Y \quad$ : Variabel independen (nilai yang diprediksikan)
a : Konstanta
$X_{1}$ dan $X_{2} \quad$ : Variabel independen
$b_{1}, b_{2} \quad:$ Koefisien regresi (nilai peningkatan ataupun penurunan)

\section{ANALISIS DAN HASIL}

\subsection{Algoritma Sistem}

Data yang diambil merupakan data stok barang tahun2018 pada PT.X dan dapat dilihat pada table 3.1

\begin{tabular}{|c|c|c|c|c|c|c|c|}
\hline \multirow[b]{2}{*}{ Bulan } & \multicolumn{7}{|c|}{2018} \\
\hline & $\begin{array}{c}\text { Frozen } \\
\text { Malaysia } \\
\text { (X1) }\end{array}$ & $\begin{array}{c}\text { Frozen } \\
\text { Lokal } \\
\text { (X2) }\end{array}$ & $\begin{array}{c}\text { Dry } \\
\text { Malaysia } \\
\text { (X3) }\end{array}$ & $\begin{array}{c}\text { Lokal } \\
\text { Dry } \\
\text { (X4) }\end{array}$ & $\begin{array}{c}\text { Non Food } \\
\text { dan Chemical } \\
\text { (X5) }\end{array}$ & $\begin{array}{l}\text { Cential } \\
\text { Kitcen } \\
\text { (X6) }\end{array}$ & $\begin{array}{c}\text { Penjualan } \\
\text { (Y) }\end{array}$ \\
\hline 01 & 233 & 383 & 8 & 842 & 270 & 2044 & 3515 \\
\hline 02 & 201 & 326 & 5 & 622 & 209 & 2243 & 3196 \\
\hline 03 & 202 & 356 & 5 & 938 & 244 & 2146 & 3484 \\
\hline 04 & 189 & 257 & 4 & 810 & 182 & 1989 & 2913 \\
\hline 05 & 173 & 314 & 5 & 557 & 203 & 2005 & 2844 \\
\hline 06 & 187 & 367 & 6 & 632 & 193 & 2307 & 3338 \\
\hline 07 & 150 & 277 & 6 & 538 & 202 & 1790 & 2718 \\
\hline 08 & 148 & 279 & 5 & 524 & 203 & 1955 & 2680 \\
\hline 09 & 147 & 283 & 7 & 484 & 175 & 1824 & 2695 \\
\hline 10 & 163 & 345 & 5 & 530 & 195 & 1931 & 2798 \\
\hline 11 & 162 & 309 & 5 & 543 & 191 & 1897 & 2751 \\
\hline 12 & 62 & 95 & 4 & 210 & 82 & 799 & 1025 \\
\hline
\end{tabular}
data stok barang.

Tabel 3.1 Data Stok Barang 


\subsubsection{Menghitung Koefisien Regresi}

Koefisien Regresi adalah suatu hal penting dalam menganalisa regresi. Manfaat dari koefisien regresi ini adalah untuk membentuk model persamaan regresi pada suatu masalah yang diteliti.

Tabel 3.2 Koefisien Regresi

\begin{tabular}{|c|c|c|c|c|c|c|c|}
\hline No & $\mathrm{X} 1$ & $\mathrm{X} 2$ & $\mathrm{X} 3$ & $\mathrm{X} 4$ & $\mathrm{X} 5$ & $\mathrm{X} 6$ & $\mathrm{Y}$ \\
\hline 1 & 233 & 383 & 8 & 842 & 270 & 2044 & 3515 \\
\hline 2 & 201 & 326 & 5 & 622 & 209 & 2243 & 3196 \\
\hline 3 & 202 & 356 & 5 & 938 & 244 & 2146 & 3484 \\
\hline 4 & 189 & 257 & 4 & 810 & 82 & 799 & 2913 \\
\hline 5 & 173 & 314 & 5 & 557 & 203 & 2005 & 2844 \\
\hline 6 & 187 & 367 & 6 & 632 & 193 & 2307 & 3338 \\
\hline 7 & 150 & 277 & 6 & 538 & 202 & 1790 & 2718 \\
\hline 8 & 148 & 279 & 5 & 524 & 203 & 1955 & 2680 \\
\hline 9 & 147 & 283 & 7 & 484 & 175 & 1824 & 2695 \\
\hline 10 & 163 & 345 & 5 & 530 & 195 & 1931 & 2798 \\
\hline 11 & 162 & 309 & 5 & 543 & 191 & 1897 & 2751 \\
\hline 12 & 62 & 95 & 4 & 210 & 82 & 799 & 1025 \\
\hline Jumlah & 2017 & 3591 & 65 & 7230 & 2249 & 21740 & 33957 \\
\hline
\end{tabular}

Tabel 3.2 Koefisien Regresi (Lanjutan)

\begin{tabular}{|c|c|c|c|c|c|}
\hline $\mathrm{X} 1 * \mathrm{Y}$ & $\mathrm{X} 2 * \mathrm{Y}$ & $\mathrm{X} 3 * \mathrm{Y}$ & $\mathrm{X} 4 * \mathrm{Y}$ & $\mathrm{X} 5 * \mathrm{Y}$ & $\mathrm{X} 6{ }^{*} \mathrm{Y}$ \\
\hline 818995 & 1346245 & 28120 & 2959630 & 949050 & 7184660 \\
\hline 642396 & 1041896 & 15980 & 1987912 & 667964 & 7168628 \\
\hline 703768 & 1240304 & 17420 & 3267992 & 850096 & 7476664 \\
\hline 550557 & 748641 & 11652 & 2359530 & 238866 & 2327487 \\
\hline 492012 & 893016 & 14220 & 1584108 & 577332 & 5702220 \\
\hline 624206 & 1225046 & 20028 & 2109616 & 644234 & 7700766 \\
\hline 407700 & 752886 & 16308 & 1462284 & 549036 & 4865220 \\
\hline 396640 & 747720 & 13400 & 1404320 & 544040 & 5239400 \\
\hline 396165 & 762685 & 18865 & 1304380 & 471625 & 4915680 \\
\hline 456074 & 965310 & 13990 & 1482940 & 545610 & 5402938 \\
\hline 445662 & 850059 & 13755 & 1493793 & 525441 & 5218647 \\
\hline 63550 & 97375 & 4100 & 215250 & 84050 & 818975 \\
\hline 5997725 & 10671183 & 187838 & 21631755 & 6647344 & 64021285 \\
\hline
\end{tabular}

Tabel 3.2 Koefisien Regresi (Lanjutan)

\begin{tabular}{|c|c|c|c|c|c|}
\hline $\mathrm{X} 1^{\wedge} 2$ & $\mathrm{X} 2^{\wedge} 2$ & $\mathrm{X} 3^{\wedge} 2$ & $\mathrm{X} 4^{\wedge} 2$ & $\mathrm{X} 5^{\wedge} 2$ & $\mathrm{X} 6^{\wedge} 2$ \\
\hline 54289 & 146689 & 64 & 708964 & 72900 & 4177936 \\
\hline 40401 & 106276 & 25 & 386884 & 43681 & 5031049 \\
\hline 40804 & 126736 & 25 & 879844 & 59536 & 4605316 \\
\hline 35721 & 66049 & 16 & 656100 & 6724 & 638401 \\
\hline 29929 & 98596 & 25 & 310249 & 41209 & 4020025 \\
\hline 34969 & 134689 & 36 & 399424 & 37249 & 5322249 \\
\hline 22500 & 76729 & 36 & 289444 & 40804 & 3204100 \\
\hline 21904 & 77841 & 25 & 274576 & 41209 & 3822025 \\
\hline 21609 & 80089 & 49 & 234256 & 30625 & 3326976 \\
\hline 26569 & 119025 & 25 & 280900 & 38025 & 3728761 \\
\hline 26244 & 95481 & 25 & 294849 & 36481 & 3598609 \\
\hline 3844 & 9025 & 16 & 44100 & 6724 & 638401 \\
\hline 358783 & 1137225 & 367 & 4759590 & 455167 & 42113848 \\
\hline
\end{tabular}


Tabel 3.2 Koefisien Regresi (Lanjutan)

\begin{tabular}{|c|c|c|c|c|c|}
\hline $\mathrm{X} 1 * \mathrm{X} 2$ & $\mathrm{X} 1 * \mathrm{X} 3$ & $\mathrm{X} 1 * \mathrm{X} 4$ & $\mathrm{X} 1 * \mathrm{X} 5$ & $\mathrm{X} 1 * \mathrm{X} 6$ & $\mathrm{X} 2 * \mathrm{X} 3$ \\
\hline 89239 & 1864 & 196186 & 62910 & 476252 & 3064 \\
\hline 65526 & 1005 & 125022 & 42009 & 450843 & 1630 \\
\hline 71912 & 1010 & 189476 & 49288 & 433492 & 1780 \\
\hline 48573 & 756 & 153090 & 15498 & 151011 & 1028 \\
\hline 54322 & 865 & 96361 & 35119 & 346865 & 1570 \\
\hline 68629 & 1122 & 118184 & 36091 & 431409 & 2202 \\
\hline 41550 & 900 & 80700 & 30300 & 268500 & 1662 \\
\hline 41292 & 740 & 77552 & 30044 & 289340 & 1395 \\
\hline 41601 & 1029 & 71148 & 25725 & 268128 & 1981 \\
\hline 56235 & 815 & 86390 & 31785 & 314753 & 1725 \\
\hline 50058 & 810 & 87966 & 30942 & 307314 & 1545 \\
\hline 5890 & 248 & 13020 & 5084 & 49538 & 380 \\
\hline 634827 & 11164 & 1295095 & 394795 & 3787445 & 19962 \\
\hline
\end{tabular}

Tabel 3.2 Koefisien Regresi (Lanjutan)

\begin{tabular}{|c|c|c|c|r|r|}
\hline $\mathrm{X} 2 * \mathrm{X} 4$ & $\mathrm{X} 2 * \mathrm{X} 5$ & $\mathrm{X} 2 * \mathrm{X} 6$ & $\mathrm{X} 3 * \mathrm{X} 4$ & $\mathrm{X} 3 * \mathrm{X} 5$ & $\mathrm{X} 3 * \mathrm{X} 6$ \\
\hline 322486 & $1.27765 \mathrm{E}+12$ & $9.67231 \mathrm{E}+12$ & 6736 & 2160 & 16352 \\
\hline 202772 & $6.95949 \mathrm{E}+11$ & $7.46896 \mathrm{E}+12$ & 3110 & 1045 & 11215 \\
\hline 333928 & $1.05438 \mathrm{E}+12$ & $9.27334 \mathrm{E}+12$ & 4690 & 1220 & 10730 \\
\hline 208170 & $1.78825 \mathrm{E}+11$ & $1.74245 \mathrm{E}+12$ & 3240 & 328 & 3196 \\
\hline 174898 & $5.15567 \mathrm{E}+11$ & $5.09217 \mathrm{E}+12$ & 2785 & 1015 & 10025 \\
\hline 231944 & $7.89216 \mathrm{E}+11$ & $9.43379 \mathrm{E}+12$ & 3792 & 1158 & 13842 \\
\hline 149026 & $4.13362 \mathrm{E}+11$ & $3.66296 \mathrm{E}+12$ & 3228 & 1212 & 10740 \\
\hline 146196 & $4.0679 \mathrm{E}+11$ & $3.9176 \mathrm{E}+12$ & 2620 & 1015 & 9775 \\
\hline 136972 & $3.59701 \mathrm{E}+11$ & $3.74912 \mathrm{E}+12$ & 3388 & 1225 & 12768 \\
\hline 182850 & $5.26683 \mathrm{E}+11$ & $5.21551 \mathrm{E}+12$ & 2650 & 975 & 9655 \\
\hline 167787 & $4.46656 \mathrm{E}+11$ & $4.43616 \mathrm{E}+12$ & 2715 & 955 & 9485 \\
\hline 19950 & 8184368750 & 79747690625 & 840 & 328 & 3196 \\
\hline 2276979 & $6.67296 \mathrm{E}+12$ & $6.37441 \mathrm{E}+13$ & 39794 & 12636 & 120979 \\
\hline
\end{tabular}

Tabel 3.2 Koefisien Regresi (Lanjutan)

\begin{tabular}{|c|c|c|}
\hline $\mathrm{X} 4 * \mathrm{X} 5$ & $\mathrm{X} 4 * \mathrm{X} 6$ & $\mathrm{X}{ }^{*} \mathrm{X} 6$ \\
\hline 227340 & 1721048 & 551880 \\
\hline 129998 & 1395146 & 468787 \\
\hline 228872 & 2012948 & 523624 \\
\hline 66420 & 647190 & 65518 \\
\hline 113071 & 1116785 & 407015 \\
\hline 121976 & 1458024 & 445251 \\
\hline 108676 & 963020 & 361580 \\
\hline 106372 & 1024420 & 396865 \\
\hline 84700 & 882816 & 319200 \\
\hline 103350 & 1023430 & 376545 \\
\hline 103713 & 1030071 & 362327 \\
\hline 17220 & 167790 & 65518 \\
\hline 1411708 & 13442688 & 4344110 \\
\hline
\end{tabular}

\subsubsection{Menyederhanakan Persamaan Regresi Linier Berganda}

Rumus perhitungan regresi linier berganda antara lain sebagai berikut :

$\sum Y=a+\mathrm{b}_{1} \sum X_{1}+\mathrm{b}_{2} \sum X_{2}+\mathrm{b}_{3} \sum X_{3}+\mathrm{b}_{4} \sum X_{4}$

$\sum Y X_{1}=a \sum X_{1}+\mathrm{b}_{1} \sum X_{1}^{2}+\mathrm{b}_{2} \sum X_{1} X_{2}+\mathrm{b}_{3} \sum X_{1} X_{3}+\mathrm{b}_{4} \sum X_{1} X_{4}+\mathrm{b}_{5} \sum X_{1} X_{5}+\mathrm{b}_{6} \sum X_{1} X_{6}$

$\sum Y X_{2}=a \sum X_{2}+b_{1} \sum X_{1} X_{2}+b_{2} \sum X_{2}^{2}+b_{3} \sum X_{2} X_{3}+b_{4} \sum X_{2} X_{4}+b_{4} \sum X_{2} X_{4}+b_{6} \sum X_{2} X_{6}$

$\sum Y X_{3}=a \sum X_{3}+b_{1} \sum X_{1} X_{3}+b_{2} \sum X_{2} X_{3}+b_{3} \sum X_{3}^{2}+b_{4} \sum X_{3} X_{4}+b_{5} \sum X_{3} X_{5}+b_{6} \sum X_{3} X_{6}$

$\sum Y X_{6}=a \sum X_{6}+b_{1} \sum X_{1} X_{6}+b_{2} \sum X_{2} X_{6}+b_{3} \sum X_{3} X_{6}+b_{4} \sum X_{4} X_{6}+b_{5} \sum X_{5} X_{6}+b_{6} \sum X_{6}^{2}$

Dengan menggunakan rumus diatas maka diperoleh persamaan sebagai berikut: 


$\begin{array}{cccccccccc}\mathrm{Y} & = & \mathrm{B} 0 & \mathrm{~B} 1 & \mathrm{~B} 2 & \mathrm{~B} 3 & \mathrm{~B} 4 & \mathrm{~B} 5 & \mathrm{~B} 6 \\ & & & \mathrm{X} 1 & \mathrm{X} 2 & \mathrm{X} 3 & \mathrm{X} 4 & \mathrm{X} 5 & \mathrm{X} 6 \\ 33957 & = & 12 & 2017 & 3591 & 65 & 7230 & 2249 & 21740 & {[1]} \\ 5997725 & = & 2017 & 358783 & 1137225 & 367 & 4759590 & 455167 & 42113848 & {[2]} \\ 10671183 & = & 3591 & 634827 & 634827 & 11164 & 1295095 & 394795 & 3787445 & {[3]} \\ 187838 & = & 65 & 11164 & 19962 & 19962 & 2276979 & 6.67296 \mathrm{E}+12 & 6.37441 \mathrm{E}+13 & {[4]} \\ 21631755 & = & 7230 & 1295095 & 2276979 & 39794 & 39794 & 12636 & 120979 & {[5]} \\ 6647344 & = & 2249 & 394795 & 6.67296 \mathrm{E}+12 & 12636 & 1411708 & 1411708 & 13442688 & {[6]} \\ 64021285 & = & 21740 & 3787445 & 6.37441 E+13 & 120979 & 13442688 & 4344110 & 4344110 & {[7]}\end{array}$

Kemudian melakukan proses eliminasi antara persamaan [1] dengan [2] :

\begin{tabular}{rlccccccrc}
33957 & $=$ & 12 & 2017 & 3591 & 65 & 7230 & 2249 & $21740[1]$ & 2017 \\
5997725 & $=$ & 2017 & 358783 & 1137225 & 367 & 4759590 & 455167 & $42113848[2]$ & 12 \\
\hline 68491269 & $=$ & 24204 & 4068289 & 7243047 & 131105 & 14582910 & 4536233 & 43849580 \\
71972700 & $=$ & 24204 & 4305396 & 13646700 & 4404 & 57115080 & 5462004 & 505366176 \\
\hline-3481431 & $=$ & 0 & -237107 & -6403653 & 126701 & -42532170 & -925771 & -461516596 & \\
{$[8]$} & & & & &
\end{tabular}

Kemudian melakukan proses eliminasi antara persamaan [1] dengan [3] :

\begin{tabular}{|c|c|c|c|c|c|c|c|c|c|c|}
\hline 33957 & $=$ & 12 & 2017 & 3591 & 65 & 7230 & 2249 & 21740 & [1] & 3591 \\
\hline 10671183 & $=$ & 3591 & 634827 & 634827 & 11164 & 1295095 & 394795 & 3787445 & [3] & 12 \\
\hline 121939587 & $=$ & 43092 & 7243047 & 12895281 & 233415 & 25962930 & 8076159 & 78068340 & & \\
\hline 128054196 & $=$ & 43092 & 7617924 & 7617924 & 133968 & 15541140 & 4737540 & 45449340 & & \\
\hline-6114609 & $=$ & 0 & $\begin{array}{l}-374877 \\
\end{array}$ & 5277357 & 99447 & 10421790 & 3338619 & 32619000 & 9] & \\
\hline
\end{tabular}

Kemudian melakukan proses eliminasi antara persamaan [1] dengan [4] :

\begin{tabular}{|c|c|c|c|c|c|c|c|c|c|}
\hline 33957 & $=$ & 12 & 2017 & 3591 & 65 & 7230 & 2249 & 21740 & [1] \\
\hline 187838 & $=$ & 65 & 11164 & 19962 & 19962 & 2276979 & $6.67296 \mathrm{E}+12$ & $6.37441 \mathrm{E}+13$ & [4] \\
\hline 2207205 & $=$ & 780 & 131105 & 233415 & 4225 & 469950 & 146185 & 1413100 & \\
\hline 2254056 & $=$ & 780 & 133968 & 239544 & 239544 & 27323748 & $8.00756 \mathrm{E}+13$ & $7.64929 E+14$ & \\
\hline 46851 & $=$ & 0 & -2863 & -6129 & -235319 & 6853798 & $8.00756 E+13$ & $29 \mathrm{E}-$ & 0 \\
\hline
\end{tabular}

Kemudian melakukan proses eliminasi antara persamaan [1] dengan [5] :

\begin{tabular}{ccccccccccc}
33957 & $=$ & 12 & 2017 & 3591 & 65 & 7230 & 2249 & 21740 & {$[1]$} & 7230 \\
21631755 & $=$ & 7230 & 1295095 & 2276979 & 39794 & 39794 & 12636 & 120979 & {$[5]$} & 12 \\
\hline 245509110 & $=$ & 86760 & 14582910 & 25962930 & 469950 & 52272900 & 16260270 & 157180200 & \\
259581060 & $=$ & 86760 & 15541140 & 27323748 & 477528 & 477528 & 151632 & 1451748 \\
\hline-14071950 & $=$ & 0 & -958230 & -1360818 & -7578 & 51795372 & 16108638 & 155728452 & {$[11]$}
\end{tabular}

Kemudian melakukan proses eliminasi antara persamaan [1] dengan [6] :

\begin{tabular}{ccccccccccc}
33957 & $=$ & 12 & 2017 & 3591 & 65 & 7230 & 2249 & 21740 & {$[1]$} & 2249 \\
6647344 & $=$ & 2249 & 394795 & $6.67296 \mathrm{E}+12$ & 12636 & 1411708 & 1411708 & 13442688 & {$[6]$} & 12 \\
\hline 76369293 & $=$ & 26988 & 4536233 & 8076159 & 146185 & 16260270 & 5058001 & 48893260 & \\
79768128 & $=$ & 26988 & 4737540 & $8.00756 \mathrm{E}+13$ & 151632 & 16940496 & 16940496 & 161312256 \\
\hline-3398835 & $=$ & 0 & -201307 & $-8.00756 \mathrm{E}+13$ & -5447 & -680226 & -11882495 & -112418996 & {$[12]$}
\end{tabular}

Kemudian melakukan proses eliminasi antara persamaan [1] dengan [7] :

\begin{tabular}{cccccccccc}
33957 & $=$ & 2017 & 3591 & 65 & 7230 & 2249 & 21740 & {$[1]$} & 21740 \\
64021285 & $=$ & 3787445 & $6.37441 \mathrm{E}+13$ & 120979 & 13442688 & 4344110 & 4344110 & {$[7]$} & 12 \\
\hline 738225180 & $=$ & 43849580 & 78068340 & 1413100 & 157180200 & 48893260 & 472627600 & & \\
768255420 & $=$ & 45449340 & $7.64929 \mathrm{E}+14$ & 1451748 & 161312256 & 52129320 & 52129320 \\
\hline-30030240 & $=$ & -1599760 & $-7.64929 \mathrm{E}+14$ & -38648 & -4132056 & -3236060 & 420498280 &
\end{tabular}

Setelah melakukan proses eliminasi antara persamaan [1] hingga persamaan [7], maka diperoleh persamaan baru yaitu sebagai berikut :

$\begin{array}{clccccccc}Y & = & B 1 & B 2 & B 3 & B 4 & B 5 & B 6 \\ -3481431 & = & -237107 & -6403653 & 126701 & -42532170 & -925771 & -461516596 & {[8]} \\ -6114609 & = & -374877 & 5277357 & 99447 & 10421790 & 3338619 & 32619000 & {[9]} \\ -46851 & = & -2863 & -6129 & -235319 & -26853798 & -8.00756 E+13 & -7.64929 E+14 & {[10]} \\ -14071950 & = & -958230 & -1360818 & -7578 & 51795372 & 16108638 & 155728452 & {[11]} \\ -3398835 & = & -201307 & -8.00756 E+13 & -5447 & -680226 & -11882495 & -112418996 & {[12]} \\ -30030240 & = & -1599760 & -7.64929 E+14 & -38648 & -4132056 & -3236060 & 420498280 & {[13]}\end{array}$

Kemudian melakukan proses eliminasi antara persamaan [8] dengan [9] : 


\begin{tabular}{|c|c|c|c|c|c|c|c|c|c|}
\hline-3481431 & $=$ & -237107 & -6403653 & 126701 & -42532170 & -925771 & -461516596 & [8] & -374877 \\
\hline-6114609 & $=$ & -374877 & 5277357 & 99447 & 10421790 & 3338619 & 32619000 & [9] & -237107 \\
\hline $1.30511 \mathrm{E}+12$ & $=$ & $8.889 \mathrm{E}+10$ & $2.40058 \mathrm{E}+12$ & -47497290777 & $1.59443 \mathrm{E}+13$ & $3.4705 \mathrm{E}+11$ & $1.73012 \mathrm{E}+14$ & & \\
\hline $1.44982 \mathrm{E}+12$ & $=$ & $8.889 E+10$ & $-1.2513 \mathrm{E}+12$ & -23579579829 & $-2.47108 \mathrm{E}+12$ & $-7.9161 E+11$ & $-7.73419 \mathrm{E}+12$ & & \\
\hline$-1.4471 \mathrm{E}+11$ & $=$ & 0 & $3.65188 \mathrm{E}+12$ & -23917710948 & $1.84154 \mathrm{E}+13$ & $1.13866 \mathrm{E}+12$ & $1.80746 \mathrm{E}+14$ & [14] & \\
\hline
\end{tabular}

Kemudian melakukan proses eliminasi antara persamaan [8] dengan [10] :

\begin{tabular}{|c|c|c|c|c|c|c|c|c|c|}
\hline-3481431 & $=$ & -237107 & -6403653 & 126701 & -42532170 & -925771 & -461516596 & [8] & -2863 \\
\hline-46851 & $=$ & -2863 & -6129 & -235319 & -26853798 & $-8.00756 \mathrm{E}+13$ & $-7.64929 \mathrm{E}+14$ & [10] & -237107 \\
\hline 9967336953 & $=$ & 678837341 & 18333658539 & -362744963 & $1.2177 \mathrm{E}+11$ & 2650482373 & $1.32132 \mathrm{E}+12$ & & \\
\hline 11108 & $=$ & 678837341 & 1453228803 & 55795782133 & $6.36722 \mathrm{E}+12$ & $1.89865 \mathrm{E}+19$ & $1.8137 \mathrm{E}+20$ & & \\
\hline-11413 & $=$ & 0 & 16880429736 & -56158527096 & $-6.24545 E+12$ & $-1.89865 \mathrm{E}+19$ & $-1.8137 \mathrm{E}+20$ & 5] & \\
\hline
\end{tabular}

Kemudian melakukan proses eliminasi antara persamaan [8] dengan [11] :

\begin{tabular}{|c|c|c|c|c|c|c|c|c|c|}
\hline-3481431 & $=$ & -237107 & -6403653 & 126701 & -42532170 & -925771 & -461516596 & [8] & -958230 \\
\hline-14071950 & $=$ & -958230 & -1360818 & -7578 & 51795372 & 16108638 & 155728452 & [11] & -237107 \\
\hline $3.33601 \mathrm{E}+12$ & $=$ & $2.272 \mathrm{E}+11$ & $6.13617 E+12$ & $-1.21409 \mathrm{E}+11$ & $4.07556 \mathrm{E}+13$ & $8.87102 \mathrm{E}+11$ & $4.42239 \mathrm{E}+14$ & & \\
\hline $3.33656 \mathrm{E}+12$ & $=$ & $2.272 \mathrm{E}+11$ & $3.22659 E+11$ & 1796796846 & $-1.2281 E+13$ & $-3.81947 \mathrm{E}+12$ & $-3.69243 E+13$ & & \\
\hline-546221520 & $=$ & $\overline{0}$ & $5.81351 \mathrm{E}+12$ & $-1.23205 E+11$ & $5.30366 \mathrm{E}+13$ & $4.70657 \mathrm{E}+12$ & $4.79163 \mathrm{E}+14$ & [16] & \\
\hline
\end{tabular}

Kemudian melakukan proses eliminasi antara persamaan [8] dengan [12] :

\begin{tabular}{|c|c|c|c|c|c|c|c|c|c|}
\hline-3481431 & $=$ & -237107 & -6403653 & 126701 & -42532170 & -925771 & -461516596 & [8] & -201307 \\
\hline-3398835 & $=$ & -201307 & $-8.00756 \mathrm{E}+13$ & -5447 & -680226 & -11882495 & -112418996 & [12] & -237107 \\
\hline $7.00836 E+11$ & $=$ & 4.773E+10 & $1.2891 \mathrm{E}+12$ & -25505798207 & $8.56202 E+12$ & $1.86364 E+11$ & $9.29065 E+13$ & & \\
\hline $8.05888 \mathrm{E}+11$ & $=$ & $4.773 \mathrm{E}+10$ & $1.89865 \mathrm{E}+19$ & 1291521829 & $1.61286 \mathrm{E}+11$ & $2.81742 \mathrm{E}+12$ & $2.66553 \mathrm{E}+13$ & & \\
\hline$-1.0505 E+11$ & $=$ & 0 & $5 \mathrm{E}+19$ & 797320036 & $8.40074 \mathrm{E}+12$ & $-2.63106 \mathrm{E}+12$ & $12 \mathrm{E}+13$ & [17] & \\
\hline
\end{tabular}

Kemudian melakukan proses eliminasi antara persamaan [8] dengan [13] :

\begin{tabular}{|c|c|c|c|c|c|c|c|c|c|}
\hline-3481431 & $=$ & -237107 & -6403653 & 126701 & -42532170 & -925771 & -461516596 & [8] & -1599760 \\
\hline-30030240 & $=$ & -1599760 & $-7.64929 E+14$ & -38648 & -4132056 & -3236060 & 420498280 & [13] & -237107 \\
\hline $5.56945 \mathrm{E}+12$ & $=$ & $3.793 E+11$ & $1.02443 E+13$ & $-2.02691 \mathrm{E}+11$ & $6.80413 E+13$ & $1.48101 \mathrm{E}+12$ & $6 E+14$ & & \\
\hline $7.12038 \mathrm{E}+12$ & $=$ & $3.793 E+11$ & $1.8137 \mathrm{E}+20$ & 9163711336 & $9.79739 \mathrm{E}+11$ & $7.67292 \mathrm{E}+11$ & $-9.97031 E+13$ & & \\
\hline$-1.5509 E+12$ & $=$ & 0 & $-1.8137 \mathrm{E}+20$ & $-2.11855 E+11$ & $6.70615 E+13$ & $7.13719 E+11$ & $8.38019 E+14$ & [18] & \\
\hline
\end{tabular}

Setelah melakukan proses eliminasi antara persamaan [8] hingga persamaan [13], maka diperoleh persamaan baru yaitu sebagai berikut :

\begin{tabular}{|c|c|c|c|c|c|c|c|c|}
\hline $\mathrm{Y}$ & $=$ & B1 & B2 & B3 & B4 & B5 & B6 & \\
\hline & & $\mathrm{x} 1$ & $x 2$ & x3 & $x 4$ & $\times 5$ & $x 6$ & \\
\hline$-1.4471 \mathrm{E}+11$ & $=$ & & $3.65188 \mathrm{E}+12$ & -23917710948 & $1.84154 \mathrm{E}+13$ & $1.13866 \mathrm{E}+12$ & $1.80746 \mathrm{E}+14$ & [14] \\
\hline-1141363104 & $=$ & & 16880429736 & -56158527096 & $-6.24545 E+12$ & $-1.89865 E+19$ & $-1.8137 E+20$ & [15] \\
\hline-546221520 & $=$ & & $5.81351 \mathrm{E}+12$ & $-1.23205 E+11$ & $5.30366 \mathrm{E}+13$ & $4.70657 \mathrm{E}+12$ & $4.79163 E+14$ & [16] \\
\hline$-1.0505 E+11$ & $=$ & & $-1.89865 E+19$ & -26797320036 & $8.40074 \mathrm{E}+12$ & $-2.63106 E+12$ & $6.62512 \mathrm{E}+13$ & [17] \\
\hline$-1.5509 E+12$ & $=$ & & $-1.8137 E+20$ & $-2.11855 E+11$ & $6.70615 E+13$ & $7.13719 E+11$ & $8.38019 E+14$ & [18] \\
\hline
\end{tabular}

Kemudian melakukan proses eliminasi antara persamaan [14] dengan [15] :

\begin{tabular}{|c|c|c|c|c|c|c|c|c|}
\hline 11 & $=$ & 12 & -2 & 1. & 12 & 4 & 14 & +10 \\
\hline$-1.14 E+09$ & $=$ & $1.7 E+10$ & $-5.616 E+10$ & $-6.245 E+12$ & $-1.984 \mathrm{E}+12$ & $-1.7821 \mathrm{E}+13$ & 15 & $E+12$ \\
\hline$-2.44 E+21$ & $=$ & $6.2 \mathrm{E}+22$ & $-4.037 E+20$ & $3.1086 \mathrm{E}+23$ & $1.9221 \mathrm{E}+22$ & $3.0511 \mathrm{E}+24$ & & \\
\hline$-4.17 E+21$ & $=$ & $6.2 \mathrm{E}+22$ & $-2.051 E+23$ & $-2.281 E+25$ & $-7.244 E+24$ & $-6.5079 E+25$ & & \\
\hline $1.725 \mathrm{E}+21$ & $=$ & 0 & $2.0468 E+23$ & $2.3119 E+25$ & $7.263 E+24$ & $6.813 E+25$ & 19 & \\
\hline
\end{tabular}

Kemudian melakukan proses eliminasi antara persamaan [14] dengan [16] :

\begin{tabular}{rlccccccc}
$-1.45 \mathrm{E}+11$ & $=$ & $3.7 \mathrm{E}+12$ & $-2.392 \mathrm{E}+10$ & $1.8415 \mathrm{E}+13$ & $1.1387 \mathrm{E}+12$ & $1.8075 \mathrm{E}+14$ & 14 & $5.814 \mathrm{E}+12$ \\
$-5.46 \mathrm{E}+08$ & $=$ & $5.8 \mathrm{E}+12$ & $-1.232 \mathrm{E}+11$ & $5.3037 \mathrm{E}+13$ & $4.7066 \mathrm{E}+12$ & $4.7916 \mathrm{E}+14$ & 16 & $3.652 \mathrm{E}+12$ \\
\hline$-8.41 \mathrm{E}+23$ & $=$ & $2.1 \mathrm{E}+25$ & $-1.39 \mathrm{E}+23$ & $1.0706 \mathrm{E}+26$ & $6.6196 \mathrm{E}+24$ & $1.0508 \mathrm{E}+27$ & & \\
$-1.99 \mathrm{E}+21$ & $=$ & $2.1 \mathrm{E}+25$ & $-4.499 \mathrm{E}+23$ & $1.9368 \mathrm{E}+26$ & $1.7188 \mathrm{E}+25$ & $1.7498 \mathrm{E}+27$ & & \\
\hline$-8.39 \mathrm{E}+23$ & $=$ & 0 & $3.1089 \mathrm{E}+23$ & $-8.663 \mathrm{E}+25$ & $-1.057 \mathrm{E}+25$ & $-6.9908 \mathrm{E}+26$ & 20
\end{tabular}


Kemudian melakukan proses eliminasi antara persamaan [14] dengan [17] :

\begin{tabular}{|c|c|c|c|c|c|c|c|c|}
\hline$-1.45 E+11$ & $=$ & $3.7 E+12$ & $-2.392 E+10$ & $1.8415 E+13$ & $1.1387 \mathrm{E}+12$ & $1.8075 E+14$ & 14 & $1.183 E+12$ \\
\hline$-1.05 E+11$ & $=$ & $1.2 \mathrm{E}+12$ & $-2.68 E+10$ & 8.4007E+12 & $-2.631 E+12$ & $6.6251 \mathrm{E}+13$ & 17 & $3.652 E+12$ \\
\hline$-1.71 E+23$ & $=$ & $4.3 E+24$ & $-2.83 E+22$ & $2.1788 E+25$ & $1.3472 E+24$ & $2.1385 E+26$ & & \\
\hline$-3.84 E+23$ & $=$ & $4.3 E+24$ & $-9.786 E+22$ & $3.0678 E+25$ & $-9.608 E+24$ & $2.4194 E+26$ & & \\
\hline $2.124 E+23$ & $=$ & 0 & $6.9563 E+22$ & $-8.891 E+24$ & $1.0956 \mathrm{E}+25$ & $-2.8094 E+25$ & 21 & \\
\hline
\end{tabular}

Kemudian melakukan proses eliminasi antara persamaan [14] dengan [18] :

\begin{tabular}{|c|c|c|c|c|c|c|c|c|}
\hline$-1.45 E+11$ & $=$ & $3.7 E+12$ & $-2.392 E+10$ & $1.8415 E+13$ & $1.1387 \mathrm{E}+12$ & $1.8075 \mathrm{E}+14$ & 14 & $9.278 E+12$ \\
\hline$-1.55 E+12$ & $=$ & $9.3 E+12$ & $-2.119 E+11$ & $6.7062 \mathrm{E}+13$ & $7.1372 \mathrm{E}+11$ & $8.3802 \mathrm{E}+14$ & 8 & $3.652 E+12$ \\
\hline$-1.34 E+24$ & $=$ & $3.4 E+25$ & $-2.219 E+23$ & $1.7086 \mathrm{E}+26$ & $1.0564 \mathrm{E}+25$ & $1.6769 \mathrm{E}+27$ & & \\
\hline$-5.66 E+24$ & $=$ & $3.4 E+25$ & $-7.737 E+23$ & $2.449 E+26$ & $2.6064 \mathrm{E}+24$ & $3.0603 E+27$ & & \\
\hline $4.321 \mathrm{E}+24$ & $=$ & 0 & $5.5176 \mathrm{E}+23$ & $-7.405 E+25$ & $7.9579 E+24$ & $-1.3834 E+27$ & 22 & \\
\hline
\end{tabular}

Setelah melakukan proses eliminasi antara persamaan [14] hingga persamaan [18], maka diperoleh persamaan baru yaitu sebagai berikut :

\begin{tabular}{|c|c|c|c|c|c|c|c|c|}
\hline $\mathrm{Y}$ & $=$ & B1 & B2 & B3 & B4 & B5 & B6 & \\
\hline & & $\times 1$ & $\times 2$ & $\times 3$ & $\times 4$ & $\times 5$ & $\times 6$ & \\
\hline $1.725 E+21$ & $=$ & & & $2.05 E+23$ & $2.31 E+25$ & $7.263 E+24$ & $6.813 E+25$ & [19] \\
\hline$-8.39 E+23$ & $=$ & & & $3.11 E+23$ & $-8.66 E+25$ & $-1.057 E+25$ & $-6.9908 E+26$ & [20] \\
\hline $2.124 E+23$ & $=$ & & & $6.96 E+22$ & $-8.89 E+24$ & $1.0956 E+25$ & $-2.8094 E+25$ & [21] \\
\hline $4.321 E+24$ & $=$ & & & $5.52 E+23$ & $-7.4 E+25$ & $7.9579 E+24$ & $-1.3834 E+27$ & [22] \\
\hline
\end{tabular}

Kemudian melakukan proses eliminasi antara persamaan [19] dengan [20] :

\begin{tabular}{|c|c|c|c|c|c|c|c|}
\hline $1.725 E+21$ & $=$ & $2.05 E+23$ & $2.31 E+25$ & $7.263 E+24$ & $6.813 E+25$ & [19] & $3.109 E+2=$ \\
\hline$-8.39 E+23$ & $=$ & $3.11 E+23$ & $-8.66 E+25$ & $-1.057 E+25$ & $-6.9908 E+26$ & [20] & $047 E+2$ \\
\hline $5.364 E+44$ & $=$ & $6.36 E+46$ & $7.19 E+48$ & $2.258 E+48$ & $2.1181 E+49$ & & \\
\hline$-1.72 E+47$ & $=$ & $6.36 E+46$ & $-1.77 E+49$ & $-2.163 E+48$ & $-1.4309 E+50$ & & \\
\hline $1.723 E+47$ & $=$ & 0 & $2.49 E+49$ & $4.4211 \mathrm{E}+48$ & $1.6427 \mathrm{E}+50$ & [23] & \\
\hline
\end{tabular}

Kemudian melakukan proses eliminasi antara persamaan [19] dengan [21] :

\begin{tabular}{|c|c|c|c|c|c|c|c|}
\hline $1.725 E+21$ & $=$ & $2.05 E+23$ & $2.31 E+25$ & $7.263 E+24$ & $6.813 E+25$ & [19] & $6.956 \mathrm{E}+22$ \\
\hline $2.124 E+23$ & $=$ & $6.96 E+22$ & $-8.89 E+24$ & $1.0956 \mathrm{E}+25$ & $-2.8094 E+25$ & [21] & $7 E+2$ \\
\hline $1.2 \mathrm{E}+44$ & $=$ & $1.42 E+46$ & $1.61 E+48$ & $5.0523 E+47$ & $4.7393 E+48$ & & \\
\hline $4.348 E+46$ & $=$ & $1.42 E+46$ & $-1.82 E+48$ & $2.2424 \mathrm{E}+48$ & $-5.7503 E+48$ & & \\
\hline$-4.34 E+46$ & $=$ & $\mathrm{O}$ & $3.43 E+48$ & $-1.737 E+48$ & $1.049 E+49$ & [24] & \\
\hline
\end{tabular}

Kemudian melakukan proses eliminasi antara persamaan [19] dengan [22] :

\begin{tabular}{|c|c|c|c|c|c|c|c|}
\hline $1.725 E+21$ & $=$ & $2.05 E+23$ & $2.31 E+25$ & $7.263 E+24$ & $6.813 E+25$ & [19] & $5.518 E+23$ \\
\hline $4.321 E+24$ & $=$ & $5.52 E+23$ & $-7.4 E+25$ & $7.9579 E+24$ & $-1.3834 E+27$ & [22] & $7 E+2$ \\
\hline $9.52 E+44$ & $=$ & $1.13 E+47$ & $1.28 \mathrm{E}+49$ & $4.0074 E+48$ & $3.7592 E+49$ & & \\
\hline $8.845 E+47$ & $=$ & $1.13 E+47$ & $-1.52 E+49$ & $1.6288 E+48$ & $-2.8316 E+50$ & & \\
\hline$-8.84 E+47$ & $=$ & $\mathrm{O}$ & $2.79 E+49$ & $2.3786 E+48$ & $3.2075 E+50$ & [25] & \\
\hline
\end{tabular}

Setelah melakukan proses eliminasi antara persamaan [19] hingga persamaan [22], maka diperoleh persamaan baru yaitu sebagai berikut :

\begin{tabular}{|c|c|c|c|c|c|c|c|c|}
\hline $\mathbf{Y}$ & $=$ & B1 & B2 & B3 & B4 & B5 & B6 & \\
\hline & & $\times 1$ & $\times 2$ & $\times 3$ & $\times 4$ & $\times 5$ & $\times 6$ & \\
\hline $1.723 E+47$ & $=$ & & & & $2.49 E+49$ & $4.4211 E+48$ & $1.6427 E+50$ & [23] \\
\hline$-4.34 E+46$ & $=$ & & & & $3.43 E+48$ & $-1.737 E+48$ & $1.049 E+49$ & {$[24$} \\
\hline$-8.84 E+47$ & $=$ & & & & $2.79 E+49$ & $2.3786 E+48$ & $3.2075 E+50$ & [25] \\
\hline
\end{tabular}

Kemudian melakukan proses eliminasi antara persamaan [23] dengan [24] :

\begin{tabular}{|c|c|c|c|c|c|c|}
\hline $1.723 E+47$ & $=$ & $2.49 E+49$ & $4.4211 E+48$ & $1.6427 E+50$ & [23] & $3.428 E+48$ \\
\hline$-4.34 E+46$ & $=$ & $3.43 E+48$ & $-1.737 E+48$ & $1.049 E+49$ & [24] & $2.492 E+49$ \\
\hline $5.907 E+95$ & $=$ & $8.54 E+97$ & $1.5155 E+97$ & $5.631 E+98$ & & \\
\hline$-1.08 E+96$ & $=$ & $8.54 E+97$ & $-4.329 E+97$ & $2.6138 E+98$ & & \\
\hline $1.671 E+96$ & $=$ & $\mathbf{O}$ & $5.8441 E+97$ & $3.0172 E+98$ & ] & \\
\hline
\end{tabular}

Kemudian melakukan proses eliminasi antara persamaan [23] dengan [25] :

\begin{tabular}{rlllllll}
$1.723 E+47$ & $=$ & $2.49 E+49$ & $4.4211 E+48$ & $1.6427 E+50$ & {$[24]$} & $2.791 E+49$ \\
$-8.84 E+47$ & $=$ & $2.79 E+49$ & $2.3786 E+48$ & $3.2075 E+50$ & {$[25]$} & $2.492 E+49$ \\
\cline { 1 - 5 } $4.81 E+96$ & $=$ & $6.95 E+98$ & $1.234 E+98$ & $4.585 E+99$ & & & \\
$-2.2 E+97$ & $=$ & $6.95 E+98$ & $5.927 E+97$ & $7.992 E+99$ & & \\
\cline { 1 - 5 } $2.682 E+97$ & $=$ & 0 & $6.4129 E+97$ & $-3.407 E+99$ & &
\end{tabular}


Setelah melakukan proses eliminasi antara persamaan [23] hingga persamaan [25], maka diperoleh persamaan baru yaitu sebagai berikut :

$\begin{array}{clccccccc}\mathrm{Y} & = & \mathrm{B} 1 & \mathrm{~B} 2 & \mathrm{~B} 3 & \mathrm{~B} 4 & \mathrm{~B} 5 & \mathrm{~B} 6 \\ \times 1 & \times 2 & \times 3 & \times 4 & \times 5 & \times 6 & \\ 1.671 \mathrm{E}+96 & = & & & & 5.8441 \mathrm{E}+97 & 3.0172 \mathrm{E}+98 & {[26]} \\ 2.682 \mathrm{E}+97 & = & & & & & 6.4129 \mathrm{E}+97 & -3.407 \mathrm{E}+99 & {[27]}\end{array}$

Kemudian melakukan proses eliminasi antara persamaan [26] dengan [27] :

\begin{tabular}{|c|c|c|c|c|c|}
\hline $1.6711 E+96$ & $=$ & $5.8441 E+97$ & $3.0172 E+98$ & [26] & $6.413 E+97$ \\
\hline $2.6825 E+97$ & $=$ & $6.4129 \mathrm{E}+97$ & $-3.407 E+99$ & [27] & $5.844 E+97$ \\
\hline $1.072 \mathrm{E}+194$ & $=$ & $3.748 E+195$ & $1.935 E+196$ & & \\
\hline $1.568 E+195$ & $=$ & $3.748 E+195$ & $-1.991 E+197$ & & \\
\hline$-1.46 \mathrm{E}+195$ & $=$ & $\mathrm{O}$ & $2.185 E+197$ & & \\
\hline & $\begin{array}{l}=-1.4605 \mathrm{E}+195 / \\
=-0.006684931\end{array}$ & $2.1848 \mathrm{E}+197$ & & & \\
\hline
\end{tabular}

Kemudian hasil $b_{6}$ dimasukkan ke persamaan [26] atau persamaan [27], dalam hal ini mengunakan persamaan [26] sebagai berikut :



Kemudian hasil $b_{5}$ dan $b_{6}$ dimasukkan ke persamaan [23] atau [24] atau [25], dalam hal ini mengunakan persamaan [23] sebagai berikut :
$1.723 \mathrm{E}+47$
$2.49177 \mathrm{E}+49$
$4.42106 \mathrm{E}+48 \quad 1.64268 \mathrm{E}+50[23]$
B4 =
$2.49177 \mathrm{E}+49$
$2.79004 \mathrm{E}+47$
$-1.0981 \mathrm{E}+48$
$\mathrm{B} 4=$ 0.006915489

Kemudian hasil $b_{4}, b_{5}$ dan $b_{6}$ dimasukkan ke persamaan [19] atau [20] atau [21] atau [22], dalam hal ini mengunakan persamaan [19] sebagai berikut :

$\begin{array}{lccccc}1.725 E+21 & & 2.0468 E+23 & 2.31185 E+25 & 7.263 E+24 & 6.813 E+25 \\ & B 3= & 2.0468 E+23 & 1.59876 E+23 & 4.5835 E+23 & -4.5544 E+23 \\ \text { B3 }= & 0.008429652 & & \end{array}$

Kemudian hasil $b_{3}, b_{4}, b_{5}$ dan $b_{6}$ dimasukkan ke persamaan [14] atau [15] atau [16] atau [17] atau [18], dalam hal ini mengunakan persamaan [14] sebagai berikut:

$\begin{array}{rlllllll}-1.447 \mathrm{E}+11 & 3.652 \mathrm{E}+12 & -2.3918 \mathrm{E}+10 & 1.84154 \mathrm{E}+13 & 1.1387 \mathrm{E}+12 & 1.8075 \mathrm{E}+14 & {[14]} \\ & \mathrm{B} 2= & 3.652 \mathrm{E}+12 & -201617979 & 1.27352 \mathrm{E}+11 & 7.1858 \mathrm{E}+10 & -1.2083 \mathrm{E}+12 & \\ \text { B2 }= & -0.0396257 & & & & \end{array}$

Kemudian hasil $b_{2}, b_{3}, b_{4}, b_{5}$ dan $b_{6}$ dimasukkan ke persamaan [8] atau [9] atau [10] atau [11] atau [12] atau [13], dalam hal ini mengunakan persamaan [8] sebagai berikut:

$\begin{array}{rrrccccc}-3481431 & -237107 & -6403653 & 126701 & -42532170 & -925771 & -461516596 & {[8]} \\ B 1= & -237107 & 253749 & 1068.04533 & -294130.774 & -58423.469 & 3085206.66 & \\ B 1=14.68295 & & & & & & \end{array}$

Kemudian hasil $b_{1}, b_{2}, b_{3}, b_{4}, b_{5}$ dan $b_{6}$ dimasukkan ke persamaan [1] atau [2] atau [3] atau [4] atau [5] atau [6] atau [7], dalam hal ini mengunakan persamaan [8] sebagai berikut:

$\begin{array}{cccccccccr} & & B 0 & B 1 & B 2 & B 3 & B 4 & B 5 & B 6 & \\ 33957 & & 12 & 2017 & 3591 & 65 & 7230 & 2249 & 21740 & 1 \\ & B 0= & 12 & 29615.517 & -142.2957565 & 0.547927378 & 49.99898888 & 141.929679 & -145.3304027 & \\ 4436.632827 & B== & 12 & 29520.367 & & & & & & \\ & B 0= & 369.719 & & & & & & & \end{array}$




$$
\begin{array}{ll}
\text { Jadi : } & \\
b_{0} & =369.719 \\
b_{1} & =14.683 \\
b_{2} & =-0.03963 \\
b_{3} & =0.00843 \\
b_{4} & =0.00692 \\
b_{5} & =0.06311 \\
b_{6} & =-0.00668
\end{array}
$$

Maka diperolehlah hasil estimasi target pemakaian stok barang sebagai berikut :

\section{$Y=369.618+14.683 \times 1+-0.0396 \times 2+0.00843 \times 3+0.00692 \times 4+0.06311 \times 5+-0.00668 \times 6$}

\section{KESIMPULAN}

Setelah menganalisis, merancang dan menguraikan sistem dalam penerapan data mining dengan algoritma regresi linier bergandauntuk estimasi target pemakaian stok barang pada PT.X dan berdasarkan rumusan masalah dari penelitian maka diambil beberapa kesimpulan yaitu :

1. Metode yang digunakan dalam mengestimasi target pemakaian stok barang adalah metode Regresi Linier Berganda. Dengan adanya aplikasi yang dibuat untuk estimasi target pemakaian stok barang dapat mempermudah PT.X dalam melakukan analisis stok barang pada bulan berikutnya.

2. Aplikasi yang dibuat berbasis desktop sehingga admin atau pengguna dapat melihat hasilnya secara langsung melalui komputer atau laptop yang telah diinstal terlebih dahulu.

3. Dengan menggunakan aplikasi tersebut, maka PT.X dengan mudah mengontrol jumlah stok barang dibulan berikutnya dengan patokan hasil penjualan dibulan sebelumnya.

\section{DAFTAR PUSTAKA}

[1] http:ojs.trigunadharma.ac.id

[2] Kusrini, Luthfiv taufiq emha (2009) Algoritma Data mining.Andi :Yogyakarta.

[3] Karina Dian Ariani.Penerapan Algoritma Regresi Linier Berganda Pada Data Pabrik Gula Rendeng Kudus.

[4] Rosa A.S.,\& M. Shalahuddin. 2013. Rekaya Perangkat Lunak Terstruktur dan Berorientasi Objek . Bandung:Informatika.

[5] Rahmat Priyanto. 2008 .Langsung Bisa Visual Basic.Net.Yogyakarta:Andi.

[6] kapanpunbisa.blogsport.com $>2013 / 5$ Pengertian Persediaan Barang.

[7] Fajar Astuti Hermawati. (2014). Data Mining. Yogyakarta: Andi .

[8] Rudi Gunawan. 2018. Data Mining Prestasi Siswa Regresi Linier Berganda. Sains dan Komputer (SAINTIKOM).Stmik Triguna Dharma.

[9] Prasetyo.2014.Data Mining.Jakarta : Andi 